\title{
Book review: What our stories teach us: a guide to critical reflection for college faculty
}

(Shadiow, L.K., 2013, Jossey-Bass)

\author{
Amir Kaviani \\ Zayed University, UAE
}

In this book, Shadiow focusses on the importance of stories as a key source of information in the lives of academics. The author believes our stories, as university teachers, can help develop a better understanding of events which include students within a university context. She likewise maintains that a close re-examination of our stories from our student days, and while teaching at university, can furnish us with multiple perspectives on how things could be done, or could have been done, in a more efficient and productive manner. Overall, Shadiow has accentuated the centrality of the concept of narrativisation of an academic's experiences and has offered a systematic approach to studying our experiences as told in our stories. The book is divided into eight chapters: the first four chapters focus on establishing the theoretical significance of stories in addition to specifying the most likely places in our biographies where we may be able to discover interesting and informative stories. Chapters 5-8 concentrate on developing an appropriate methodology to seek and analyse patterns in our stories in order to understand and develop meanings around events, based on a set of theoretical principles which will be briefly explored in this review.

According to Shadiow, we are able to adjust or perhaps change our focus in teaching, if we begin to seek out and reflect on stories of noteworthy events or interactions with our students - stories that are more often than not forgotten or overlooked. She further states that we can also look for enlightening stories in our lives as students, and in our academic life - i.e. in our CVs, in the syllabi and memories of courses we have developed or taught, and in our professional writing: the journal articles we have written and the reviews we have received. The author also maintains that each one of these information sources may include some critical incidents or "breached norms" as Bruner (1996) refers to them, which we can analyse in order to discover the major themes that can inform and improve our approach to understanding our students and our own teaching practice. For example, she writes about her own experience of losing her work-study job during her undergraduate years at university, and subsequently of one occasion when she started teaching at university, when her students suggested a different plan from what she had originally suggested on the syllabus. The main proposition of the book is that our histories as students and academics, in particular the practice of teaching and learning at university itself, create a context rich with stories involving both educators and students. Accordingly, telling these stories can furnish us with valuable insights into, and multiple perspectives on, critical events in the stories. Drawing on Bruner's (1990) work, Shadiow also highlights the importance of our interdependent selves when narrating stories, i.e., self at the time the incident happened, self now, the telling self and the envisaged self, or possible selves in the future based on a better appreciation of the prominent events in the story. This is based on the premise that by looking at a single event at different points of time, from different vantage points and for different audiences, we can alter and perhaps improve our perception and understanding of the event, and the actions and responses of those involved.

Throughout the book, the author provides interesting personal accounts that highlight the importance of encounters with students in various situations that are filled with some type of "tension" or 
"moments of discomfort" and "disruption". The author believes that reassessing the role of the teacher, the role of the learner and the role of content and context in each critical incident can add to the breadth of our vision. In other words, by re-examining each incident, we are looking at the underlying reason for the occurrence of the critical incident - e.g. a student objecting to a teaching method or behaving in an unorthodox manner - at the way we as academics have responded to this event and the ensuing changes in our teaching and/or students' learning. As we tell our stories, Shadiow claims, our "roles, claims and challenges" become clearer for us because as academics, we have a set of assumptions that guide our work. She believes that in teaching practice, we have three different sets of assumptions: causal assumptions, prescriptive assumptions and paradigmatic assumptions. Causal assumptions point to our expectations about how a certain pedagogical action should lead to a specific reaction. Prescriptive assumptions, on the other hand, reveal our values with respect to what we do for our students and how they can benefit from it. Paradigmatic assumptions, according to Shadiow, are linked to our fundamental beliefs about what constitutes the right course of action for learning to take place within a specific context.

In sum, in her book, Shadiow posits that by following a systematic method of looking for stories of note in our lives as students and as academics, we can seek patterns and analyse them based on the three sets of assumptions mentioned above. This, she believes, can not only give us a better understanding of ourselves as educators but can also furnish us with a deeper understanding of how our expectations, values and beliefs can influence our teaching and how these assumptions can be re-adjusted in different contexts, with different content and with different students. By telling these stories, we engage in a process of reviewing and possibly challenging the Weltanschauung and philosophies about teaching and learning that we have embraced over the years. Such an undertaking, the author contends, can indicate and result in increased interest in our work, which can in turn lead to a better comprehension and appreciation of our students and of our role as academics.

Shadiow's work is of great significance in the context of higher education in the Middle East and in particular in the UAE for the purposes of pedagogy and research. This is due to the fact that most professors who teach at universities in the UAE come from Western countries and are familiar with Western learning and teaching traditions which do not necessarily correspond with a student's learning experiences in the Middle East. Because of this, the professor can benefit from engaging in novel ways of looking at things, how things could be done more efficiently, i.e. s/he should engage in a process of looking at lived experiences through telling stories. Such an approach is in line with Bruner's (1984) argument that a "life lived" and a "life told" are characteristically different, revealing cultural patterns and faultlines:

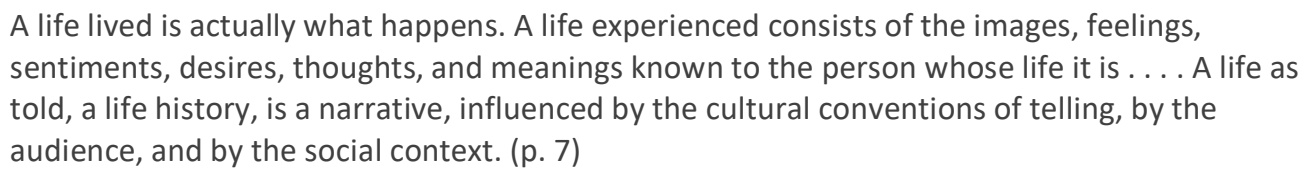

A life lived is actually what happens. A life experienced consists of the images, feelings, sentiments, desires, thoughts, and meanings known to the person whose life it is ... A life as told, a life history, is a narrative, influenced by the cultural conventions of telling, by the audience, and by the social context. (p. 7)

In addition, Shadiow's work could be of great interest to an academic in the UAE because it suggests a method of analysis of our lives as academics, akin to Sartre's progressive-regressive method of investigation, which emphasises the relationship between human beings and their social environments by locating key events in the life of an individual and moving backward and forward to better understand the preceding and the subsequent events that shape the individual's persona. As a professor in the UAE, one can expect that diverse cultural and educational backgrounds will create events that constitute a rich repertoire of significant and perhaps difficult moments of pausing, intense thinking and deciding on the best course of action. As early as 1915, Alexander Philip, the Scottish solicitor, argued: 
It is by and through obstructions and these only that we featurise or denote our Experience. It is by the breaks, the turnings in the road that we cognise its course. It is by the line of rocks and breakers that we define the shore. But we must not mistake the turnings for the roadway nor the shore for the ocean.

What Shadiow suggests in her book is possibly one of the most viable ways of understanding how our troubled moments as students and as university educators should inhere in the way we theorise about the best teaching practices and about practical and reasonable ways of dealing with our students' learning problems. In addition, through adopting the narrative approach proposed by Shadiow, we can better appreciate why theories so commonly fail to be enacted in proper praxis, and we can also acquire specialised and in-depth knowledge that we need to be informed, prepared, skilled and effective teachers. Shadiow's book is an interesting, informative and useful resource for every academic who aspires to a better self in his/her job, who does not become discouraged by irregularities and troubled moments and looks at them as signposts that help her/him navigate a tortuous route. Shadiow provides such academics with ample theoretical principles and practical guidelines to partake in a process of sense-giving and sense-making with regard to experience; as such, her book is highly recommended.

\section{References}

Bruner, E. M. (1984). The opening up of anthropology. In E. M. Bruner (Ed.) (1984). Text, play, and story: the construction and reconstruction of self and society. Proceedings of the 1983 annual meeting. Washington: American Enthological Association, pp. 1-16.

Bruner, J. (1990). Acts of meaning. Cambridge: Harvard University Press.

Bruner, J. (1996). The culture of education. Cambridge: Harvard University Press.

Philip, A. (1915). Essays towards a theory of knowledge. Project Gutenberg.

Sartre, J. P. (1963). Search for a method. New York: Knopf. 